THe Department of Geology has recently acquired, through the generosity of Mrs. E. M. Reid, a valuable collection of fruits and seeds from the Pliocene of County Durham, Germany and Russia, most of which have been figured by her in the Journal of Botany and the Quarterly Journal of the Geological Society. In conjunction with M. P. Marty, Mrs. Reid has also presented nearly 700 fruits and seeds from the Pliocene of France. The Department of Botany has been presented with more than seven hundred drawings by the late Dr. A. H. Church. Most of the drawings were made in connexion with the preparation of further volumes of "Types of Floral Mechanism", of which only one volume, that of spring flowers, was published in 1908. A number of the drawings are in colour, but probably those which are of most interest are line and wash drawings of stages in the development of the different floral types. The drawings, accompanied by descriptions and manuscript notes, mostly ready for publication, are probably among the most accurate that have been made. "The Department has also received about 900 gatherings of flowering plants and 400 gatherings of lichens and mosses which have been made by C. G. and E. G. Bird in the Mackenzie Bay area of the east coast of Greenland. The collection is well preserved and is valuable as coming from so far north. H. G. Vevers has collected about 500 numbers of flowering plants and cryptogams on the Oxford University Exploration Club's Faroes Biological Expedition. The Museum Herbarium has been so far very poor in plants from this area, and the collection, therefore, is the beginning towards filling an important gap, for many of the forms described appear to be very similar to some occurring in the British Isles, the land nearest to them.

\section{North Pole Station}

News from the Soviet North Pole Expedition is given by the Soviet Union Year Book Press Service. It would appear that the floating station is drifting southward towards north-east Greenland. This was to be expected from what is known of the general trend of Arctic currents. Under wind action there are easterly or westerly deviations from this main direction. The drift to the south has averaged $2 \cdot 35$ miles a day since the establishment of the station, and the speed is increasing as the East Greenland Current is approached. During the first month the drift to the south was 84 miles and during the fourth month it was 95 miles. A sounding in the vicinity of the Pole showed a depth of 2,346 fathoms, and it is unlikely that much greater depths occur in the Arctic Sea. The intermediate warm layer of water which Nansen discovered north of Spitsbergen and explained as being saline Atlantic water has been found near the Pole at depths between 12 and 30 fathoms. At a depth of 36 fathoms the water temperature was found to be almost zero, with a steady fall with increasing depth to $-0 \cdot 67^{\circ} \mathrm{C}$. at the bottom. It is of interest to note that the inner parts of the Arctic Sea in the vicinity of the Pole are rich in plankton and have much larger animal life. The floes are even and flat. The smooth floes were, of course, reported by Peary, and did much to facilitate his march to the Pole.

\section{The Indian Oil Industry}

ON the whole, the Indian oil industry figures less prominently in the general Press than that of other countries, notably the United States of America. The erroneous conclusion may, therefore, be drawn that methods of exploration, production and refining are not so far advanced in that country as in others. A recent paper by P. Evans (Current Science, 5, March 1937), however, clarifies this position by giving a succinct account of modern technique with particular reference to its application to conditions encountered in India and Burma. The main producing oil-fields are at Yenangyaung, Singu and Lanywa in Burma; Digboi in Assam; and Khaur in north-west India. Exhaustive geological mapping has been carried out over a vast area of India and Burma, and maps are available ranging in scale from 4 to 16 inches per mile. Numerous exploratory wells have been drilled, and the fact that the six leading companies in India have spent six crores of rupees on unsuccessful drilling indicates that neither time nor money has been spared in the search for new producing fields. Failure to locate such fields can in no circumstances be attributed to lack of scientific aid, for the help of the geophysicist and the geologist has been freely enlisted in India and Burma. The former has such adjuncts at his disposal as the torsion balance, seismograph, magnetometer and potentiometer; and the latter the aeroplane for field reconnaissance of large areas, the core-drill for putting down shallow-bores to check structure, and laboratory methods of palæontology, micro-palæontology and micro-petrology for the examination of core-samples.

In India, as in most other countries, the rotary drilling system is extensively used for all deep drilling, and such cognate problems as the best type of mud fluid to employ, the accurate diagnosis of strata traversed by the drill, and the prevention of crooked drilling have all been encountered and combatted scientifically by experts. Depths such as those attained in America have not yet been achieved in India, but there are records of wells drilled to more than a mile and a half, and in some cases very difficult territory has had to be negotiated. Though problems of optimum rate of production from individual wells and from fields as a whole are not absent in India and Burma, they are fortunately less acute than in some other countries. This is largely due to the fact that in India the mineral rights, with a few exceptions only, are vested in the State, and in several cases a field is worked by one company alone, while in Burma drilling is regulated by the warden of the oil-fields assisted by an advisory board. The principle of employing competent, fully-qualified geologists, chemists and engineers is followed in both India and Burma, and the technical literature now available as the result of exhaustive research and 
correlation of data from the results of past experience on the part both of the oil companies and of the Geological Survey of India is ample testimony of the progress made in the Indian oil industry since its inception.

\section{Lister Institute of Preventive Medicine}

AT the annual general meoting of the Lister Institute, held on June 2, the Governing Body presented the Institute's forty-third annual report. The report contains an interesting summary of the research work done during the year. Respecting viruses, a team of workers has continued the study of a possible virus agent in the causation of acute rheumatism and rheumatic diseases, Dr. Salaman has continued his investigation of the antigenic structure of vaccinia virus, and Sir John Ledingham has studied the peculiar relationship that exists between the filterable viruses of rabbit myxomatosis and rabbit fibroma. Dr. Felix and Miss Pitt have continued their investigations on the antigenic constitution of the typhoid bacillus, and on the virulence and immunizing properties of bacteria. Much work has also been carried out on vitamins and nutrition, and Prof. Robison has continued his studies on calcification. The two Svedberg ultracentrifuges, provided by a grant from the Rockefeller Foundation, have proved satisfactory, and have been used in the investigation of virus bodies and of proteins. The National Collection of Type Cultures, housed at the Institute, has distributed during the year some 5,000 cultures, and 200 new strains of microorganisms have been added to the Collection.

\section{The Night Sky in November}

THE moon is new on November 3 at $4^{\mathrm{h}}$ and full on November 18 at $8^{\text {h }}$ U.T. On November 20 , the moon occults the 3rd magnitude star $\zeta$ Tauri, the disappearance as seen from Greenwich taking place at $5^{\mathrm{h}} 33^{\mathrm{m}}$ and the reappearance at $6^{\mathrm{h}} 28^{\mathrm{m}}$. On November 21, $\vee$ Geminorum (magnitude $4 \cdot 1$ ) is occulted, the reappearance being observable at Greenwich at $0^{\mathrm{h}} 8^{\mathrm{m}}$. Conjunctions of the moon with the planets occur as follows-Venus on November $1^{\mathrm{d}} 8^{\mathrm{h}}$ : Jupiter on November $9^{\mathrm{d}} 7^{\mathrm{h}}$ : Mars on November $9^{\mathrm{d}} 21^{\mathrm{h}}$ : Saturn on November $14^{\mathrm{d}} 16^{\mathrm{h}}$. On November 4, Uranus is in opposition to the sun; on this date the planet may be located between 0 Arietis and $\omega$ Arietis, stars of about the same apparent magnitude as that of Uranus, which presents a small disk of about $3 \frac{1}{2}^{\prime \prime}$ in diameter. Both Jupiter and Mars are low in the early evening sky, but Saturn, southing at about $20^{\mathrm{h}}$ in the middle of the month, is better placed for observation. Venus is a bright morning star and is near Spica ( $\alpha$ Virginis) on November 6. The variable star Algol ( $\beta$ Persei) is well placed for observation throughout the night. The change in light may be easily seen about $1 \frac{1}{2}$ hours before and after the following times: November $10^{\mathrm{d}} 2 \cdot 2^{\mathrm{h}}, 12^{\mathrm{d}} 23 \cdot 0^{\mathrm{h}}, 15^{\mathrm{d}} 19 \cdot 8^{\mathrm{h}}$ and $30^{\mathrm{d}} 3 \cdot 9^{\mathrm{h}}$. The Leonid meteors are expected between November 9 and 20 , the radiant point being about $10^{\circ}$ north of the bright star Regulus. The maximum of the
Andromedids is due about November 20, the radiant being near $\gamma$ Andromedæ. By midnight in midNovember, the brilliant collection of our winter stars comprising those of the constellation of Orion, pre. ceded by Aldebaran and the Pleiades and followed by Procyon and Sirius, is well above the eastern horizon.

\section{Announcements}

Dr. Günther JUST, director of the Institute of Genetics at the University of Greifswald, has been appointed director of the corresponding institute of the Health Office of the Reich at Berlin-Dahlem.

AT the annual statutory meeting of the Royal Society of Edinburgh, held on October 25, the following Council was elected: President: Sir D'Arcy Wentworth Thompson; Vice-Presidents. Prof. F. A. E. Crew ; Lieut.-Colonel A. G. M'Kendrick ; Principal J. C. Smail ; Prof. J. Walton; Dr. James Watt; Prof. E. T. Whittaker; General Secretary: Prof. James P.-Kendall; Secretaries to Ordinary Meetings: Dr. A. C. Aitken and Dr. C. H. O'Donoghue; Treasurer: Dr. E. M. Wedderburn; Curator of Library and Museum: Dr. Leonard Dobbin.

Prof. M. Polanyi writes with reference to his article on the recent international scientific meeting at the Palais de la Découverte (Nature, Oct. 23, p. 710) : "In my article on the International Congress in Paris reference is made to a conversation with German delegates. This statement originates from an editorial correction of the manuscript. My own report stated that the remarks on a better under. standing between German and French peoples were made at the opening meeting." Prof. Polanyi's original words, to the editorial modification of which he refers, were as follows: "Later in the evening I noticed a spy thrusting himself into my conversation with one of the German delegates. The German spoke about a better understanding of the German and French people-three delegates using the same, no doubt officially approved, phrase."

ThE Oxford University Press announces that the treatise on the "Science of Petroleum", under the editorship of Dr. A. E. Dunstan, Prof. A. W. Nash, Sir Henry Tizard and Dr. Benjamin T. Brooks, will be published in December or January. It has been decided to issue the work in four volumes, instead of three, as previously announced. The preparation of a Supplementary Volume, with ac. counts of work which has appeared while the treatise has been in the press, is under consideration.

Erratum.-In the paragraph, based on Dr. J. Needham's Herbert Spencer Lecture, and entitled "Organization of Human Society", which appears in NATURE of October 16, p. 679, there is a sentence which reads : "He suggests that a democracy which produces is the form of society most in accord with what we know of the biological basis of human common life." The word "experts" should have been printed after the word "produces". 